\title{
The effect of cotton-based collection methods on eosinophil cationic protein (ECP) concentrations detected in saliva
}

\author{
Teck Yee Wong \\ David Koh \\ Andrew Wee \\ Vivian $\mathrm{Ng}$ \\ Yong Tat Koh \\ Zhenjie Sum \\ Gerald Koh \\ Department of Community, \\ Occupational and Family Medicine, \\ Yong Loo Lin School of Medicine, \\ National University of Singapore, \\ Singapore
}

Correspondence: Teck Yee Wong Department of Community, Occupational and Family Medicine, Yong Loo Lin School of Medicine, National University of Singapore, MD3, 16 Medical Drive, Singapore 117597

Tel +6565166930

Fax +6567791489

Email cofwty@nus.edu.sg
Background: Salivary eosinophil cationic protein (ECP) level has the potential to be an assessment tool for asthma. Its measurement is not well-established and needs standardization. We studied how passive drool (PD) and two commercial devices, Salivette ${ }^{\circledR}$ (cotton-based device) and Sorbette ${ }^{\circledR}$ (cellulose-cotton-based-device), may affect ECP levels during collection among healthy subjects.

Methods: Study I $(n=10)$ involved direct sampling of healthy adult subjects with Salivette ${ }^{\circledR}$ and Sorbette ${ }^{\circledR}$. Study II $(n=33)$ involved 'indirect' sampling of previously collected PD by both devices.

Results: In study I, ECP levels were detected in all PD samples but only in three with Sorbette ${ }^{\circledR}$ and none with Salivette ${ }^{\circledR}$ (collection order: PD, Sorbette ${ }^{\circledR}$ and Salivette ${ }^{\circledR}$ ). We changed the order of collection (Salivette ${ }^{\circledR}$, Sorbette ${ }^{\circledR}$, PD) and the results were similar (ECP levels detected in all PD samples, three with Sorbette ${ }^{\circledR}$ and only one with Salivette $\left.{ }^{\circledR}\right)$. In study II, ECP levels in saliva collected by PD was $12.8 \mu \mathrm{g} / \mathrm{L}$ (median) and using Sorbette ${ }^{\circledR}$ and Salivette ${ }^{\circledR}$ were $<2.0 \mu \mathrm{g} / \mathrm{L}$ and $3.4 \mu \mathrm{g} / \mathrm{L}$ respectively $(\mathrm{p}<0.01)$. ECP levels in PD correlated with Sorbette $^{\circledR}\left(r_{\mathrm{s}}=0.79\right.$, $\mathrm{p}<0.01)$ and Salivette ${ }^{\mathbb{B}}\left(\mathrm{r}_{\mathrm{s}}=0.62, \mathrm{p}<0.01\right)$.

Conclusion: Compared to PD, saliva collected using cotton or cellulose-based collection devices resulted in lower measurable ECP levels.

Keywords: salivary ECP, collection methods

\section{Introduction}

The use of saliva as a diagnostic tool has many advantages as it contains many constituents and is noninvasive compared to traditional methods like phlebotomy (Koh and Koh 2007). A possible clinical use is measuring eosinophil cationic protein (ECP) in saliva of asthmatic patients. ECP measured in saliva in adults has been found to correlate with asthma severity (Schmekel et al 2001). ECP has also been used as an assessment and management tool for asthma (Koh et al 2007).

One unresolved methodological issue is the appropriateness of collection methods for different biomarkers. There are currently two main techniques of saliva collection: cotton-based and noncotton-based. Study data show that different collection devices may influence the amount of different biomarkers collected (Shirtcliff et al 2001; Strazdins et al 2005).

The measurement of ECP in saliva is not well established and needs standardization before it can become an accepted method of assaying in patients. The purpose of our study is to determine if ECP measurements are affected by different collection methods.

Three methods commonly used for collection of saliva are: passive drool (PD), Sorbette $^{\circledR}$ (Visispear ${ }^{\mathrm{TM}}$, Becton, Dickinson and Co., San Jose, CA, USA) and Salivette ${ }^{\circledR}$ (Sarstedt Inc., Rommelsdorf, Germany). Sorbette ${ }^{\circledR}$ is a cellulose-cotton tip “eyespear” 
applicator placed under the tongue to absorb saliva into a capillary tube in its stem. Salivette ${ }^{\circledR}$ has a cotton absorption roll which absorbs saliva when placed in the mouth. Saliva from both Sorbette ${ }^{\circledR}$ and Salivette ${ }^{\circledR}$ can be extracted by centrifugation.

\section{Materials and methods}

We conducted two studies. The first compared concentrations of ECP from healthy adult subjects by using the three different collection methods. In the second study, we dipped both cotton-based and cellulose-cotton devices (Salivette ${ }^{\circledR}$ and Sorbette ${ }^{\circledR}$, respectively) into previously collected salivary samples and measured the ECP concentrations from all 3 methods. All participants were not allowed to eat and drink an hour before saliva collection. Participation was voluntary and the study was approved by National University of Singapore Institutional Review Board (IRB). The study objectives and protocol was explained to all participants before sample collection and written consent were obtained.

\section{Study I}

Thirty saliva samples were initially obtained from 10 healthy adults using the three saliva collection protocols at a single time point in the order of PD, Sorbette ${ }^{\circledR}$ and Salivette ${ }^{\circledR}$. We repeated the process with another 10 healthy adults but in the reverse order of collection (Salivette ${ }^{\circledR}$, Sorbette ${ }^{\circledR}$, and PD). Exclusion criteria were participants below 21 years of age, with periodontal or oral disease and any corticosteroid usage in the prior month.

For the PD method, subjects allowed saliva to flow to the base of the mouth before drooling into a sterile tube (Falcon $\left.{ }^{\circledR}\right)$ via a sterilized funnel provided until $2 \mathrm{mls}$ of saliva was obtained. The tubes used for saliva collection were made of polypropylene, which prevents ECP from sticking to the walls of the tube. Sorbette ${ }^{\circledR}$ and Salivette ${ }^{\circledR}$ devices were placed under the tongue of the participants, where saliva was absorbed for 60 seconds.

The saliva-saturated cotton roll of Salivette ${ }^{\circledR}$ were placed in their original tubes, which is made of polypropylene and centrifuged at $1,000 \mathrm{~g}$ for 15 minutes at $4{ }^{\circ} \mathrm{C}$ for saliva extraction. For the Sorbette ${ }^{\circledR}$ devices, 2 were used to absorb saliva from each participant. The stems of the Sorbette ${ }^{\circledR}$, made from polypropylene, were cut, inverted and placed in the tubes for centrifuging at 1,500 $\mathrm{g}$ for 20 minutes at $4{ }^{\circ} \mathrm{C}$. Saliva extracted from both Sorbette ${ }^{\circledR}$, Salivette ${ }^{\circledR}$ and passive drool were aliquoted into tubes, stored at $-80{ }^{\circ} \mathrm{C}$, then analyzed. This was to facilitate consistency as our saliva samples were frozen before thawing for Study II. Another reason for a single freeze-thaw cycle was to break down mucopolysaccharides that may interfere with pipetting (Worthman et al 1990).

\section{Study II}

Thirty-three healthy adults participated in this study with exclusion critera being the same as study I. Five mls of saliva samples were collected from participants using the PD method with no time limit imposed.

The saliva samples from study II were stored at $-80^{\circ} \mathrm{C}$ for at least one day before they were removed to thaw completely before being analyzed. The saliva samples were used directly for the assay after thawing without any pretreatment. Saliva samples taken from each participant were divided into three separate polypropylene tubes. Saliva in one of the tubes was used to detect ECP by the PD method. Sorbette ${ }^{\circledR}$ and Salivette ${ }^{\circledR}$ collection devices were dipped into the saliva samples in the other two separate tubes and allowed to adequately absorb saliva to saturation. The extraction of saliva follows the method as described above and immediately analyzed. The idea of dipping both Sorbette ${ }^{\circledR}$ and Salivette ${ }^{\circledR}$ into the saliva collected was modified from the sample preparation of Shirtcliff and colleagues (2001). By dipping the collection devices into the stock tube of saliva collected by PD, we made the assumption that saliva was collected by all 3 methods were at the same time point.

For both studies, ECP levels in saliva were analyzed by fluoroenzymeimmunoassay using an ImmunoCAP ${ }^{\circledR}$ 100 machine from Pharmacia (detection limit of ECP $>2 \mu \mathrm{g} / \mathrm{l}$ ). The reaction volume required for ECP analysis is $40 \mu \mathrm{l}$.

Statistical analysis was performed by SPSS version 15.0 (SPSS Inc, Chicago, IL, USA). For study II, comparison was performed using Wilcoxon signed-rank test and Spearman's test for correlation.

\section{Results}

For study I, ECP levels were detected in all the saliva samples collected using the PD method using the 1st order of collection. The mean and median ECP concentration in saliva for passive drool were $85.3 \mu \mathrm{g} / \mathrm{L}(\mathrm{SD}=67.2)$ and $58.9 \mu \mathrm{g} / \mathrm{L}$ (interquartile range [IQR] 25.7 to $155.8 \mu \mathrm{g} / \mathrm{L}$ ). ECP levels were not detected in all the saliva samples collected using the Salivette ${ }^{\circledR}$ method and in seven saliva samples collected by the Sorbette ${ }^{\circledR}$ method. The three samples with detectable ECP using the Sorbette ${ }^{\circledR}$ method $(3.78,4.32$, and $6.23 \mu \mathrm{g} / \mathrm{L})$ was significantly lower than the PD ECP levels (155, 16.5, and $158, \mu \mathrm{g} / \mathrm{L})$. 
Table I Study II: Saliva ECP levels ( $\mu \mathrm{g} / \mathrm{L}$ ) measured by using Salivette ${ }^{\circledR}$ and Sorbette ${ }^{\circledR}$ dipped into previously collected salivary samples by passive drool $(n=33)$

\begin{tabular}{llllll}
\hline $\begin{array}{l}\text { Collection } \\
\text { method }\end{array}$ & Mean & SD & Median & $\begin{array}{l}\text { Interquartile } \\
\text { range }\end{array}$ & Range \\
\hline Passive drool & 42.5 & 58.4 & 12.8 & $3.1-55.2$ & $2.0-195.9$ \\
Salivette $^{\circledR}$ & 3.6 & 3.1 & 2.0 & $2.0-3.5$ & $2.0-14.2$ \\
Sorbette $^{\circledR}$ & 14.2 & 24.7 & 3.4 & $2.0-12.8$ & $2.0-123.0$ \\
\hline
\end{tabular}

Abbreviations: $\mathrm{ECP}$, eosinophil cationic protein; SD, standard deviation.

When we reversed the order of salivary collection, ECP levels were again detected in all the PD samples. Mean and median ECP concentration for PD was $76.7 \mu \mathrm{g} / \mathrm{L}(\mathrm{SD}=60.0)$ and $76.6 \mu \mathrm{g} / \mathrm{L}$ (IQR 16.3 to $137.3 \mu \mathrm{g} / \mathrm{L}$ ), respectively. ECP level was only detected in one sample collected using Salivette $^{\circledR}(2.82 \mu \mathrm{g} / \mathrm{L})$ and three by Sorbette ${ }^{\circledR}(4.52,5.33$, and $7.94 \mu \mathrm{g} / \mathrm{L})$. The Sorbette ${ }^{\circledR}$ values were also lower compared to their corresponding PD ECP levels $(135,7.42$, and $144 \mu \mathrm{g} / \mathrm{L})$.

For study II, median ECP levels were significantly higher in PD $(12.8 \mu \mathrm{g} / \mathrm{L})$ compared to Sorbette ${ }^{\circledR}(3.4 \mu \mathrm{g} / \mathrm{L}$, $\mathrm{p}<0.01)$ and Salivette ${ }^{\circledR}$ ECP levels $(<2.0 \mu \mathrm{g} / \mathrm{L}, \mathrm{p}<0.01)$ (Table 1). Salivary ECP levels using PD correlated with Sorbette $^{\circledR}\left(r_{s}=0.79, p<0.01\right)$ and Salivette ${ }^{\circledR}\left(r_{s}=0.62\right.$, $\mathrm{p}<0.01$ ) (Figure 1).

\section{Discussion}

Commercial devices currently available for saliva collection are potentially useful. However, the use of cotton-based absorbent materials in collection devices can profoundly affect the results of immunoassays for certain biomarkers. It has been shown that results for testosterone, dehydroepiandrosterone (DHEA), progesterone and estradiol were found to be higher while those for sIgA were lower when cotton-based absorbent materials are used (Schmekel et al 2001). For other biomarkers such as cortisol, DHEA-S, and cotinine, the results are not affected by the use of cotton-based methods.

Our study showed that for salivary ECP, the use of cotton-based and cellulose-based collection devices results in lower measurable levels of ECP as compared to passive drool.

We also found that PD had another advantage in that the amount of saliva collected can be visually confirmed during sampling. For Salivette ${ }^{\circledR}$ and Sorbette ${ }^{\circledR}$ collection devices, we could not confirm the amount of saliva collected at the time of sampling.

A hypothesis to explain these differences is ECP binding to cotton fibres of the Salivette ${ }^{\circledR}$ and Sorbette ${ }^{\circledR}$ because ECP has a sticky nature and is known to bind to negatively
A

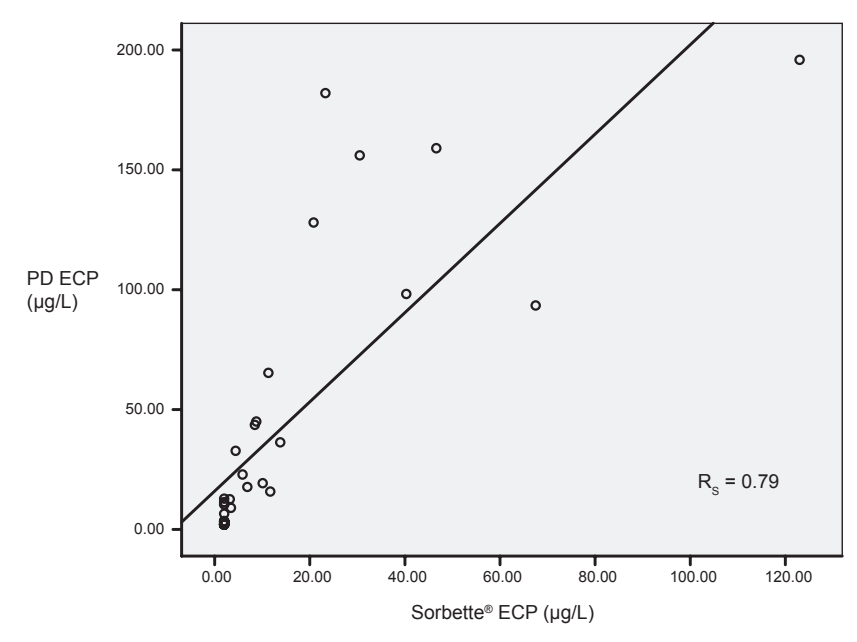

B

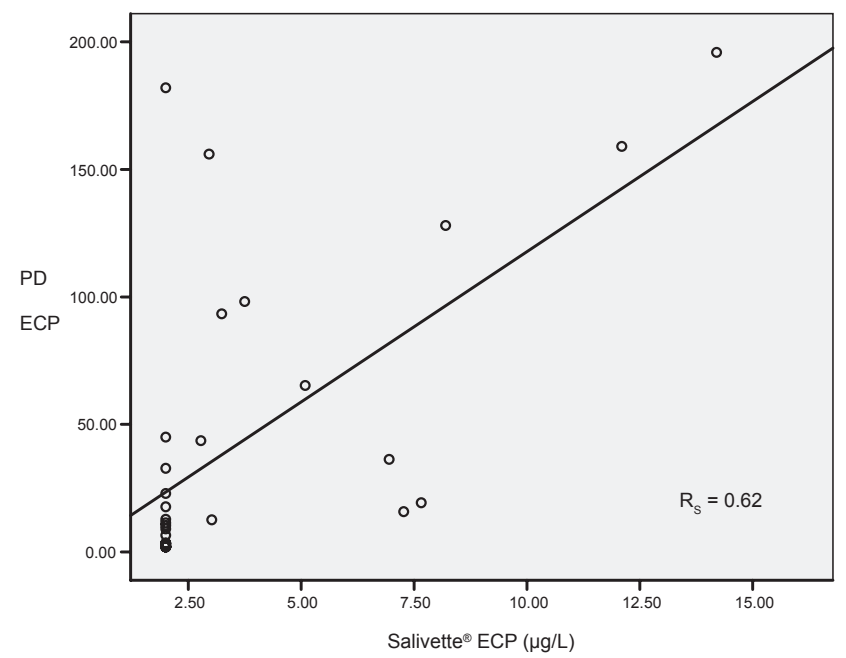

Figure I Study II (A) Correlation between Sorbette ${ }^{\circledR}$ and passive drool (PD) eosinophil cationic protein (ECP) levels (B) Correlation between Salivette ${ }^{\circledR}$ and passive drool ECP levels.

charged molecules (Venge et al 1999). The relatively lower ECP values obtained from Salivette ${ }^{\circledR}$ compared to Sorbette $^{\circledR}$ could also be explained by a greater amount of cotton used in Salivette ${ }^{\circledR}$.

We also found that the concentration of ECP measured in both cotton-based collection devices correlates with PD. Hence, even though the former may not quantify true absolute ECP levels in saliva, they could be used as a marker of changes in saliva ECP.

In conclusion, our study shows that the use of cotton or cotton-cellulose-based devices for saliva collection results in lower levels of ECP detected compared to PD. Such devices should not be used to quantify absolute ECP levels in saliva but could possibly be useful to monitor relative changes in levels of PD ECP. 


\section{Acknowledgments}

This work was supported by Niche Area program Research Grant (Number: R-186-000-077-101) by the Yong Loo Lin School of Medicine, National University of Singapore.

\section{References}

Koh DSQ, Koh GCH. 2007. The use of salivary biomarkers in occupational and environmental medicine. Occup Environ Med, 64:202-10.

Koh GCH, Shek LPC, Goh DYT, et al. 2007. Eosinophil cationic protein: Is it useful in asthma? A systematic review. Respir Med, 101:696-705.
Schmekel B, Ahlner J, Malmström M, et al. 2001. Eosinophil cationic protein (ECP) in saliva: a new marker of disease activity in bronchial asthma. Respir Med, 95:670-5.

Shirtcliff EA, Granger DA, Schwartz E, et al. 2001. Use of salivary biomarkers in biobehavioral research: cotton-based sample collection methods can interfere with salivary immunoassay results. Psychoneuroendocrinology, 26:165-73.

Strazdins L, Meyerkort S, Brent V, et al. 2005. Impact of saliva collection methods on sIgA and cortisol assays and acceptability to participants. J Immunol Methods, 307:167-71.

Venge P, Byström J, Carlson M, et al. 1999. Eosinophil cationic protein (ECP): molecular and biological properties and the use of ECP as a marker of eosinophil activation in disease. Clin Exp Allergy, 29:1172-86.

Worthman CM, Stallings JF, Hofman LF. 1990. Sensitive salivary estradiol assay for monitoring ovarian function. Clin Chem, 36:1769-73. 